\title{
Use of Areca Nut and The Need for Awareness - A Reflection from Pakistan
}

\author{
Syed Uzair Mahmood*, Nouman Mansoor Ali and Ushna Jawwad Awan \\ Department of medicine, Jinnah Sindh Medical University, Pakistan
}

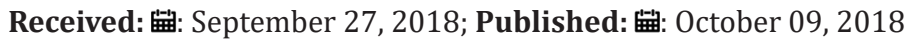

*Corresponding author: Syed Uzair Mahmood, MBBS, Medical Student, Jinnah Sindh Medical University, Karachi, Pakistan

\begin{abstract}
Habitual chewing of areca nut is the fourth most common drug habit in the world, after alcohol, nicotine and caffeine. Around 600 million people around the world practice it. A major extract from the nut is arecholine - an odourless oily liquid, which is a nicotinic based alkaloid. This is not only done for pleasure but also, as a traditional practice in many parts of the world - more specifically in South East Asia. Its traditional influence can be judged by the fact that many places have been named after the areca nut in their native languages. Regarding arecholine's chemical structure, it has a basic nitrogen which gives it alkaloid like properties. The major source of arecholine is the areca nut which is grown as an agricultural crop in many countries and among these, India is the major cultivator. Being a muscarinic and nicotinic agonist, it has many significant uses, such as its use in slowing down the progression of Alzheimer's, but due to its carcinogenic effects it has never been approved to be used commercially.

Clinical evidence has indicated and proved that the use of areca nut causes several types of head and neck cancers, as to effects on intracellular levels of GSH, and on tumor suppressing gene P53 are quite evident. As a South Asian country, Pakistan is also suffering from this endemic habit of chewing areca nut and its devastating effect on general health. Due to its excessive use, Pakistan is now a part of those countries where oral cancer is very common. Several failed attempts have been made in the past to curb its use, but unless the Government of Pakistan takes any legislative step, these attempts can be made successful. Sadly, the government is silent on this condition and due to this, the private sector has to step in to fix this problem on their own.
\end{abstract}

\section{Introduction}

Arecholine, conventionally known as Arecoline [1], is the major product or extract of areca nuts. There are various types of chemical compounds found in the areca nut, but Arecholine is the major or dominant psychoactive compound, which has a number of effects on man [2]. Areca nut, or betel nut, is ranked fourth among the most commonly abused substance in the world [3]. Studies have shown the association of chewing areca nut with cancer in humans, particularly oral cancers $[4,5]$. Cancers of head and neck region are regarded as the 6thmost commonly occurring cancers in the world. However, in South and Central Asia, they are ranked as the 3rd most common types of cancer [6,7].

\section{Background}

Historically, the use of areca nuts dates back to around 4000 years ago in Philippines, Thailand and Indonesia [8]. Their use is deeply incorporated into some of the most ancient traditions of world such as the Indian subcontinent, where areca nut or betel nut chewing habit is found to be a part of the Harappa Empire [9]. The use of areca nut is endemic to many countries and regions of world. It is used more extensively in South Asia and South-East Asia as compared to its use in Central Asia [8]. The combination of tobacco with areca nuts is a modern innovation; however it was not practiced in ancient times. Places like Penang in Malaysia, KoMak in Thailand, Guwahati in Assam (A state of India and Fua Maluka in Maldives, show the cultural, traditional and individual importance for areca nut, as they are named in their respective native languages.

\section{Properties}

Arecholine is an alkaloid in nature [2]. Like other alkaloids, it contains three major elements in its structure, namely Carbon, Hydrogen and Nitrogen. Among these elements, nitrogen is basic, which gives arecholine its alkaloid properties [10]. It is an oillike compound showing solubility to alcohol, ether and water [1]. There are a number of other chemical compounds found in areca nuts such as gallic acid, nipecotic acid, and etc. [11]. Among these compounds, Arecholine is the major alkaloid, which is extracted from areca nuts [2]. Arekolin, Taeniolin, Arecaidine methyl ester, and Methylarecaidin are some of the other common names by which Arecholine is known. Its chemical formula is C8H13 NO2, with an I.U.P.A.C. name of "methyl1-methyl-1,2,5,6-tetrahydropyridine3-carboxylate" and having a molecular framework as Aliphatic heteromonocyclic compound [10]. As arecholine is basic in nature, it forms salt when reacted with acid [12]. 


\section{Sources}

Arecholine comes from the areca nuts, which itself is a fruit of a palm tree [10] Specie of this palm tree is known as Areca catechu, and is commonly grown in Tropical Pacific, in regions of East Africa and more prominently in Asia. It is believed that it was first originated in a region which is now known as Philippines [13] Areca catechu has other common names such as areca nut palm, areca palm, Indian nut, betel palm and Pinang palm. In 2003, Food and Agricultural Organization also known as "FAO" which an agency of United Nations is, published a survey report, in which information regarding areca nut growing was given. In this report, it was stated that growing of areca nut has been elevated for the past couple of decades and many countries grow it as their major agricultural crop, among which India was listed as its largest producer [14]

\section{Uses}

Arecholine is a muscarinic and nicotinic agonist. In animal practices, it has shown effects as a parasympathomimetic and vermifuge drug [10]. Its effects are reported on M1, M2, M3 and M4 subtypes of muscarinic receptors as a partial agonist [15-17]. Clinical trials of arecholine have shown marked effects on degenerative neuronal diseases, such as Alzheimer's disease. When administered via intravenous (IV) route, arecholine has shown improvement in spatial and verbal memory of an Alzheimer's patient [1]. It is also reported, that arecholine has shown therapeutic effects on dementia caused by Alzheimer's [18], but its use as a therapeutic agent or drug has not been approved [1]. Arecholine is also useful in diseases such as Tardive Dyskinesia (TD), which is characterized by a cholinergic deficiency in the brain [19]. Other effects such as antianxiety, euphoric, arousing and sedative are also reported in multiple researches; it is also stated to be an aphrodisiac drug in some historical references [20,21]. Arecholine has also shown effects as an antiparasitic drug against helminth's [22]. However, due to its carcinogenic properties, arecholine is not approved as a first line of drug for any for therapeutic purposes yet [23].

\section{Arecholine A Carcinogen}

Researches have shown Betel quid as the major factor of causing oral cancer [24], in which areca nut is the key component [25]. Arecholine is found to be the major carcinogen and etiological factor of cancer in areca nut $[5,26]$. Areca nuts have shown to cause different types of cancers such as oral, pharyngeal, and oropharyngeal cancer, and are also responsible for poor oral conditions and hygiene [27]. Comparative studies from India showed that the risk of oropharyngeal cancer increased to about 4 times in areca nut chewers as compared to non-chewers [28]. Another large-scale research showed that areca nut is also responsible for esophageal cancer [4]. Evidence has shown that areca nut used with tobacco increases the risk of cancer by multiple folds [28-30]. Stats for head and neck cancer are very high, ranking it as the 6thcommonly occurring cancer in world [6]. Whereas, in developing countries such as Pakistan, India, Srilanka and Bangladesh in South Asia, conditions are worse, where it is the most common cause of cancer [6,31]. Around $84 \%$ of oropharyngeal cancers are reported from developing countries, specifically from
Asia [32]. Animal researches confirmed that, areca nut used alone or in a combination with tobacco cause cancer [33].

\section{Mode of Action as A Carcinogen}

Lab examination and studies have shown that Arecholine is an alkaloid that is a major precursor for four different types of $\mathrm{N}$-nitrosamines. Among these four, two have shown positivity as carcinogens [34]. Arecholine has shown cytotoxicity, genotoxicity as well as growth limiting properties on different kind of cells in the human body. Specially, on oral mucosal fibroblast and keratinocytes of gingiva [35,36] Clinical evidences have shown its effects on cellular esterase and GSH levels where it is found that arecholine depletes both of them intracellularly within 24 hours of use [24] Extracts of areca nut have been recognized worldwide as key etiological factor for oral cancer due to their specific stimulation on prostaglandins and cyclooxygenase-2 pathway which creates a proinflammatory condition in the mouth [37]. Arecholine also inhibits P53 gene and promotes proapoptotic genes which concludes its activity as a tumor formation promoting compound [38,39].

\section{Conditions in Pakistan}

Addiction of areca nuts is considered as the 4thmost common abusive practice after alcohol, nicotine, and caffeine throughout the globe [40]. Currently, a certain amount of Earth's population is using areca nuts, and it is endemic in many parts of Asia, including Pakistan [41]. Areca nut is not separately chewed in Pakistan; rather it is served in the form of a quid known locally as 'paan'. Paan also contains manganese, which is known to cause neurotoxicity, however, its affordability makes it appealing to the public [42]. Oral cancer is now one of the most commonly occurring cancers in South Asia. One in every four newly diagnosed cancers is oral cancer in Pakistan, Srilanka, Bangladesh and India [6,43]. In 2013, a local dental health camp was arranged in Karachi, where around $30 \%$ patients were diagnosed with oral submucosal fibrosis. Out of these, $85 \%$ were daily chewers of areca nut and paan [44]. Researches have shown that the habit of chewing areca nut and associated products, such as paan and gutka, is also common among university students in Karachi, who claim that its use is fashionable.

\section{Efforts from Pakistan}

Oncologists in Pakistan have repeatedly stated that new cases of oral cancer are reported to have occurred in young teens and adults due to their heavy consumption of sweet areca nuts (supari or chalia), who mostly belong to the low socioeconomic class [45]. Researches and surveys have shown that populations of different areas of Pakistan are aware of the harmful effects of areca nut. In Islamabad $54 \%$ of population was well aware, and 29\% were slightly aware, while in Karachi, 56-61\% of population was aware about the dreadful outcomes caused by areca nuts [46]. The Punjab Food Authority (PFA) banned the use of areca nut in an attempt to address the problems caused by it. However, the Traders of Lahore Association challenged this ban in court just within a week of its implementation $[47,48]$. While in Sindh, a bill was presented in Assembly by the Sindh Health Department to completely ban areca nut and other harmful products in May 2017, but there has been 
no update regarding the issue by the government [49]. Pakistan Medical Association (PMA) demanded the ban on areca nut in Sindh again in February 2018 [50]. Private sector of Pakistan, especially in Karachi, is working on various types of awareness programs and trainings to tackle this problem on their own [51].

\section{Conclusion}

The habit of areca nut chewing is now considered one of the most common addictions, with around 600 million people practicing it worldwide [52]. This habit is also endemic in Pakistan, which is rapidly increasing day by day in the country, especially in Karachi [40]. A significant population of Pakistan has indulged in this addiction. According to surveys, this habit can also be passed on to children [53], which puts the upcoming generation in great danger. Many doctors in the country have already recognized the condition [45]. Red splashes of residual areca nut can be seen around the streets [40], yet the Government of Pakistan has not taken strict measures to overcome this issue. The most affected people belong to the low socioeconomic class, who are unable to afford the costly treatment of cancer.

\section{References}

1. (2018) Showing metabocard for Glucosylceramide.

2. Lord GA, Lim CK, Warnakulasuriya S, Peters TJ (2002) Chemical and analytical aspects of areca nut. Addiction biology 7(1): 99-102.

3. Tanwir F, Altamash M, Gustafsson A (2008) Influence of betel nut chewing, dental care habits and attitudes on perceived oral health among adult Pakistanis. Oral health \& preventive dentistry 6(2): 89-94.

4. Akhtar S (2013) Areca nut chewing and esophageal squamous-cell carcinoma risk in Asians: A meta-analysis of case-control studies. Cancer Causes \& Control 24(2): 257-265.

5. Tsai CL, Kuo MY, Hahn LJ, Kuo YS, Yang PJ, et al. (1997) Cytotoxic and cytostatic effects of arecoline on oral mucosal fibroblasts. Proceedings of the National Science Council, Republic of China 21(4): 161-167.

6. Warnakulasuriya S (2009) Global epidemiology of oral and oropharyngeal cancer. Oral oncology 45(4-5): 309-316.

7. Petersen PE (2003) The World Oral Health Report 2003: continuous improvement of oral health in the 21st century-the approach of the WHO Global Oral Health Programme. Community Dentistry and oral epidemiology 31: 3-24.

8. https://web.archive.org/web/20081015222435/http://infopedia. nl.sg/articles/SIP_883_2004-12-17.html

9. sadomovalex's blog (2018).

10. https://www.drugbank.ca/drugs/DB04365

11. http://flipper.diff.org/app/items/1371

12. Windholz M, Budavari S, Stroumtsos LY, Fertig MN (1976) The Merck index. An encyclopedia of chemicals and drugs.

13. (2018) U.S. National Plant Germplasm System.

14. (2015) FAO Statistical Yearbook: World Food and Agriculture.

15. Ghelardini C, Galeotti N, Lelli C, Bartolini A (2001) M1 receptor activation is a requirement for arecoline analgesia. Il Farmaco 56(5-7): 383-385.

16. Xie D, Chen L, Liu C, Zhang C, Liu K, et al. (2004) Arecoline Excites the Colonic Smooth Muscle Motility via M3 Receptor in Rabbits. Chinese Journal of Physiology 47(2): 89-94.
17. Yang YR, Chang KC, Chen CL, Chiu TH (2000) by Activating the M-Muscarinic Receptor. Chinese Journal of Physiology 43(1): 23-8.

18. Shih YT, Chen PS, Wu CH, Tseng YT, Wu YC, et al. (2010) Arecoline, a major alkaloid of the areca nut, causes neurotoxicity through enhancement of oxidative stress and suppression of the antioxidant protective system. Free Radical Biology and Medicine 49(10): 1471-1479.

19. van Harten PN, Tenback DE (2011) Tardive dyskinesia: clinical presentation and treatment. In International review of neurobiology 98: 187-210.

20. Javed F, Bello Correra FO, Chotai M, Tappuni AR, Almas K (2010) Systemic conditions associated with areca nut usage: a literature review. Scandinavian journal of public health 38(8): 838-844.

21. Chu NS (2002) Neurological aspects of areca and betel chewing. Addiction biology 7(1): 111-114.

22. Yusuf H, Yong SL (2002) Oral submucous fibrosis in a 12-year-old Bangladeshi boy: a case report and review of literature. International journal of paediatric dentistry 12(4): 271-276.

23. Saikia JR, Schneeweiss FH, Sharan RN (1999) Arecoline-induced changes of poly-ADP-ribosylation of cellular proteins and its influence on chromatin organization. Cancer letters 139(1): 59-65.

24. Chang MC, Ho YS, Lee PH, Chan CP, Lee JJ, et al. (2001) Areca nut extract and arecoline induced the cell cycle arrest but not apoptosis of cultured oral KB epithelial cells: association of glutathione, reactive oxygen species and mitochondrial membrane potential. Carcinogenesis 22(9): $1527-1535$

25. Papke RL, Horenstein NA, Stokes C (2015) Nicotinic activity of arecoline, the psychoactive element of" Betel Nuts", suggests a basis for habitual use and anti-inflammatory activity. PloS one. 10(10): e0140907.

26. Pan H, Li Y, Huang L, Zhou X, Lu Y, et al. (2018) Development and validation of a rapid LC-MS/MS method for simultaneous quantification of arecoline and its two active metabolites in rat plasma and its application to a pharmacokinetic study. Journal of pharmaceutical and biomedical analysis 154: 397-403.

27. Al Rmalli SW, Jenkins RO, Haris PI (2011) Betel quid chewing as a source of manganese exposure: total daily intake of manganese in a Bangladeshi population. BMC public health 11(1): 85.

28. Nandakumar A, Anantha N, Pattabhiraman V, Prabhakaran PS, Dhar M, et al. (1996) Importance of anatomical subsite in correlating risk factors in cancer of the oesophagus-report of a case-control study. British journal of cancer 73(10): 1306-1311.

29. Phukan RK, Ali MS, Chetia CK, Mahanta J (2001) Betel nut and tobacco chewing; potential risk factors of cancer of oesophagus in Assam, India. British journal of cancer 85(5): 661-667.

30. Znaor A, Brennan P, Gajalakshmi V, Mathew A, Shanta V, et al. (2003) Independent and combined effects of tobacco smoking, chewing and alcohol drinking on the risk of oral, pharyngeal and esophageal cancers in Indian men. International journal of cancer 105(5): 681-686.

31. Moore SR, Johnson NW, Pierce AM, Wilson DF (2000) The epidemiology of mouth cancer: a review of global incidence. Oral diseases 6(2): 65-74.

32. Lambert R, Hainaut P (2007) Epidemiology of oesophagogastric cancer. Best practice \& research Clinical gastroenterology 21(6): 921-945.

33. on the Evaluation IW. Betel-quid and Areca-nut Chewing.

34. Hoffmann D, Brunnemann KD, Prokopczyk B, Djordjevic MV (1994) Tobacco-specific N-nitrosamines and Areca-derived N-nitrosamines: chemistry, biochemistry, carcinogenicity, and relevance to humans. Journal of Toxicology and Environmental Health 41(1): 1-52.

35. Jeng JH, Chang MC, Hahn LJ (2001) Role of areca nut in betel quidassociated chemical carcinogenesis: current awareness and future perspectives. Oral oncology 37(6): 477-492. 
36. Sundqvist K, Liu Y, Nair J, Bartsch H, Arvidson K, et al. (1989) Cytotoxic and genotoxic effects of areca nut-related compounds in cultured human buccal epithelial cells. Cancer research 49(19): 5294-5298.

37. Jeng JH, Ho YS, Chan CP, Wang YJ, Hahn LJ, et al. (2000) Areca nut extract up-regulates prostaglandin production, cyclooxygenase- 2 mRNA and protein expression of human oral keratinocytes. Carcinogenesis. 21(7): $1365-1370$.

38. Goan YG, Chang HC, Hsu HK, Chou YP, Cheng JT (2005) Risk of p53 gene mutation in esophageal squamous cell carcinoma and habit of betel quid chewing in Taiwanese. Cancer science 96(11): 758-765.

39. Li Y, Ma J, Guo Q Duan F, Tang FA, et al. (2009) Overexpression of MMP2 and MMP-9 in esophageal squamous cell carcinoma. Diseases of the Esophagus 22(8): 664-667.

40. Williams S, Malik A, Chowdhury S, Chauhan S (2002) Sociocultural aspects of areca nut use. Addiction biology 7(1): 147-154.

41. Gupta PC, Warnakulasuriya S (2002) Global epidemiology of areca nut usage. Addiction biology 7(1): 77-83.

42. Wang LY, You SL, Lu SN, Ho HC, Wu MH, et al. (2003) Risk of hepatocellular carcinoma and habits of alcohol drinking, betel quid chewing and cigarette smoking: a cohort of 2416 HBsAg-seropositive and 9421 HBsAg-seronegative male residents in Taiwan. Cancer Causes \& Control 14(3): 241-250.

43. Moore SR, Johnson NW, Pierce AM, Wilson DF (2000) The epidemiology of mouth cancer: a review of global incidence. Oral diseases 6(2): 65-74.

\section{ISSN: 2574-1241}

DOI: 10.26717/BJSTR.2018.09.001839

Syed Uzair Mahmood. Biomed J Sci \& Tech Res

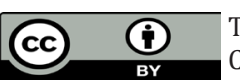

This work is licensed under Creative Commons Attribution 4.0 License

Submission Link: https://biomedres.us/submit-manuscript.php
44. https://www.dentalnewspk.com/hus-oral-cancer-awareness-program

45. https://www.thenews.com.pk/archive/print/344941-awareness-keyto-treatment-say-experts

46. Khan MS, Bawany FI, Shah SR, Hussain M, Arshad MH, et al. (2013) Comparison of knowledge, attitude and practices of betelnut users in two socio-economic areas of Karachi. JPMA. The Journal of the Pakistan Medical Association 63(10): 1319-1325.

47. https://www.pakistantoday.com.pk/2018/01/28/pfa-bans-theproduction-and-sale-of-betel-nuts

48. https://www.pakistantoday.com.pk/2018/01/29/betel-nut-traders-tomove-in-court-against-pfas-ban

49. https://tribune.com.pk/story/1410543/chewing-tobacco-might-soonbanned-across-sindh

50. https://fp.brecorder.com/2018/02/20180212343175

51. https://www.issup.net/knowledge-share/events/2016-05/drugprevention-project-pakistani-schools

52. Nelson BS, Heischober B (1999) Betel nut: a common drug used by naturalized citizens from India, Far East Asia, and the South Pacific Islands. Annals of emergency medicine 34(2): 238-243.

53. Gupta PC, Ray CS (2004) Epidemiology of betel quid usage. AnnalsAcademy of Medicine Singapore. 33(4): 31-36.

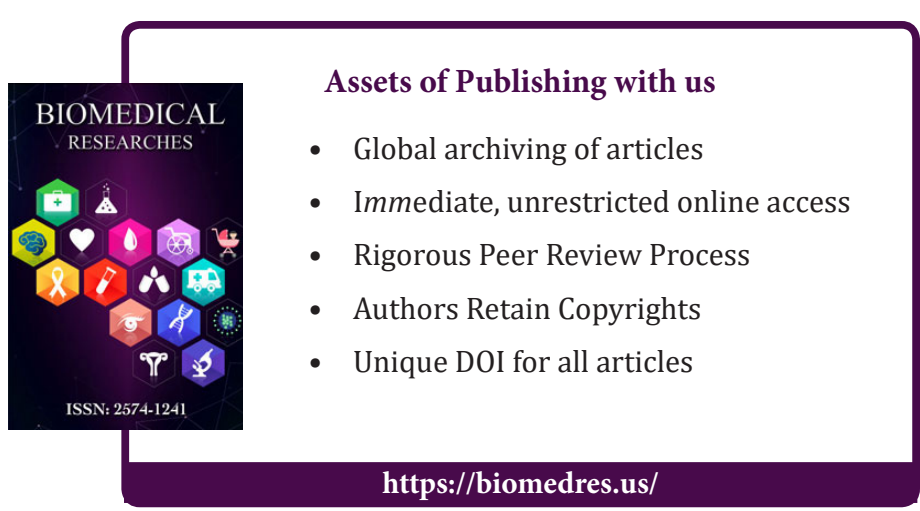

Cite this article: Syed Uzair Mahmood, Nouman Mansoor Ali, Ushna Jawwad Awan. Use of Areca Nut and The Need for Awareness - A Reflection 